\title{
Szerkezeti biológiai kutatások röntgenkrisztallográfiai alapokon a BME VBK ABÉT Biostruct laboratóriumban
}

\author{
NYÍRI Kinga ${ }^{\mathrm{a}, \mathrm{b}}$, LEVELES Ibolya ${ }^{\mathrm{a}}$ b, NAGY Gergely Nándor ${ }^{\mathrm{a}, \S}$ és VÉRTESSY G. Beáta ${ }^{\mathrm{a}, \mathrm{b},{ }^{*}}$ \\ ${ }^{a}$ BME, VBK Alkalmazott Biotechnológiai és Élelmiszertudományi tanszék, Szt Gellért tér 4, 1111, Budapest, Magyarország \\ ${ }^{b}$ MTA TTK Enzimológiai Intézet, Magyar Tudósok krt 2, 1117, Budapest, Magyarország
}

\section{Integrált szerkezeti biológia}

Az életjelenségek kémiai, biokémiai alapokon való feltárása régi vágya a biológia és kémia határmezsgyéjén dolgozó kutatóknak. A más kifejezéssel molekuláris élettudományok néven illetett tudományterület első nagy eredményei olyan makromolekulákhoz kötődtek, melyek háromdimenziós térszerkezetét régóta ismerjük (kiemelt példa itt a DNS kettős spirál, vagy az első fehérjeszerkezetek). Ezektől az eredményektől elindulva mára odáig jutottunk, hogy szinte futószalagon történik a rendkívül felgyorsult adatgyüjtés a makromolekulák és komplexeik térszerkezetéről és dinamikus tulajdonságairól. Emellett a rendszerszintü biológiai és kémiai kutatások óriási adathalmazokat generálnak sejtek, szervezetek teljes genomjáról, proteomjáról, metabolomjáról (azaz a sejt, illetve szervezet összes génjének, fehérjéjének, anyagcsere intermedierjeinek összességéről, ezek pontos szerkezete mellett). Az egyre gyorsuló adatgyüjtést a módszerek elképesztő arányú fejlődése teszi lehetővé, ezen belül kiemelendő a molekuláris biológia restrikciós enzimekre és polimeráz láncreakcióra támaszkodó eszköztára, mely mára már a genommérnökséget is lehetővé tévő nagyhatékonyságú kromoszóma-szerkesztést is biztosítani tudja (ZFN, TALEN; CRISPR/Cas9 rendszerek).

Molekuláris ismereteink ilyen örömteli robbanásszerü gyarapodása véleményünk szerint most azt az igazi kihívást rejti magában, hogy a rendszerszintü adatgyüjtésekkel generált információtömeget értelmezni tudjuk, és ezt az értelmezést okosan fel tudjuk használni életminőségünk javítására. Az ezredfordulón a molekuláris biológiai kutatások egyik legnagyobb horderejü projektje a humán genom feltérképezése volt. Azonban a nukleotidszekvencia megismerése bár elengedhetetlen, még sem elégséges ahhoz, hogy megértsük az összes szervezetben lejátszódó folyamatot és azok szabályozását, melyek a géntermékeken keresztül valósulnak meg. Több ezer olyan gént azonosítottak, melyek ismeretlen funkcióval rendelkező fehérjét kódolnak. Az aminosav-szekvencia (elsődleges fehérjeszerkezet) ismert ezen esetekben, de ez gyakran nem elegendő az ismeretlen funkciók és ezen fehérjék élettani szerepének feltérképezésére. A fehérjék térszerkezetének ismerete alapján azonban megalapozott módon következtetni lehet a lehetséges funkciókra. A fehérjék térszerkezete, azaz a fehérjét alkotó atomok térbeli helyzetének ismerete, a tudomány jelenlegi állása szerint csak mérések alapján határozható meg megbízható módon, jóllehet a szerkezeti bioinformatika egyre hatékonyabb módszerekkel dolgozik. Napjaink kutatásában ezért kiemelkedő szerepet töltenek be fehérje térszerkezet vizsgálatát lehetővé tevő módszerek: a röntgenkrisztallográfia, a mágneses magrezonancia (NMR) és a krioelektron mikroszkópia, melyek egymással részben átfedő, részben kiegészítő technikák. A kutatócsoportunk által alkalmazott röntgenkrisztallográfiás módszer legnagyobb előnye, hogy nem limitáló tényező a vizsgálni kívánt objektum mérete, kisméretü peptid hormonok, fehérje komplexek sőt egész vírusok atomi felbontású 3D szerkezete is meghatározható. Emellett gyakran alkalmazzák ezt a módszert gyógyszerjelöltek vizsgálatára mivel a kristályosítható gyógyszercélpont fehérjék esetében a többi módszerhez viszonyítva viszonylag könnyen kapható szerkezeti információ a különböző jelöltek kötődéséről. A fehérjeröntgenkrisztallográfia módszerének széles körü elterjedéséhez nagyban hozzájárul, hogy jelenleg az ezen a területen érdekelt kutatók számára elérhetők nagy intenzitású szinkrotron sugárforrások. Továbbá az egyre inkább automatizálható számítógépes szerkezetmeghatározó szoftverek fejlesztése folyamatosan könnyíti az adatok értelmezését.

A több fehérjéből álló, nagyobb komplexek esetében ezeket gyakran kiegészítik kisszögű röntgenszórás (SAXS), hidrogén-deutérium cserén alapuló tömegspektrometriás (HDX-MS), kémia keresztkötésen illetve fluoreszcencia alapú távolság meghatározási módszerekkel. Továbbá a különböző spektroszkópiai (fluoreszcencia, CD, UV-VIS, NIR, Raman) és termodinamikai (ITC) technikák is fontos hozzáadott értéket képviselő információt tudnak szolgáltatni a fehérjék szerkezeti változásairól, és ezeknek a fehérjeműködésre gyakorolt hatásairól. A fentiekben felsorolt technikák együttes alkalmazására való törekvést nevezzük összefoglaló néven integrált szerkezeti biológiai megközelítésnek.

\section{A Biostruct laboratórium infrastruktúrája}

A Biostruct laboratórium, amely 2011 óta a Budapesti Müszaki és Gazdaságtudományi Egyetem Alkalmazott Biotechnológia és Élelmiszertudományi Tanszékén müködik, lehetővé teszi a legmodernebb eszközök alkalmazását röntgenkrisztallográfiai kutatások területén. Jól diffraktáló fehérjekristályok előállítása mind a mai napig

\footnotetext{
* Tel.: 463-3854 ; fax: 463-3854; e-mail: vertessy@mail.bme.hu

$\S$ Jelenlegi munkahely: University of Oxford, Division of Structural Biology, Roosevelt Drive, Oxford OX3 7BN, UK
} 
sok erőfeszítést igényel a kutatók részéről. A fehérjekrisztallográfiai kutatómunka első lépése minden esetben, olyan megfelelő oldatkörülmény megtalálása, amelyben kristályképződés lehetséges. Az ehhez szükséges nagy áteresztőképességű szürővizsgálatok költség és időhatékony módon történő elvégzését a Biostruct laboratóriumban található Mosquito folyadékkezelő robot (TTP Labtech) teszi lehetővé számunkra, mely 50-2000 nanoliteres térfogatok pontos pipettázására alkalmas (1. ábra).

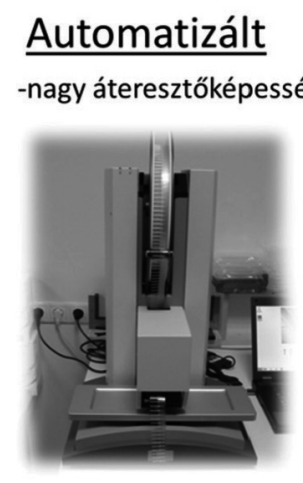

\section{Rocklmager \\ (Formulatrix) \\ Kristálymonitorozó \\ termosztatált robot, UV /VIS mikroszkópokkal}

\section{Mosquito (TTPLabtech) kis térfogatokat kimérő pipettázó robot}
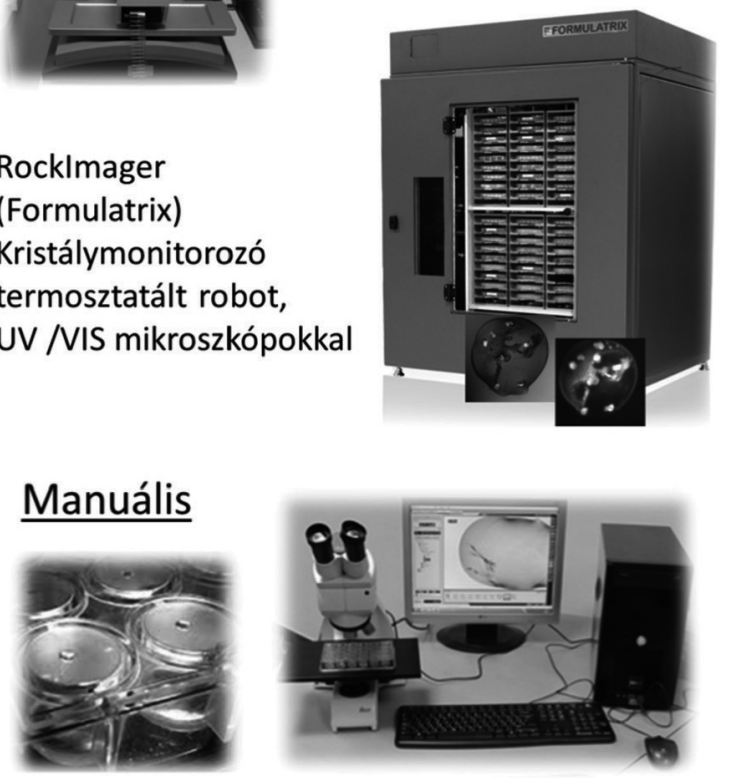

1. ábra. Kristályosítás a Biostruct laborban

A szürővizsgálatok során 96-lyukú tálcákon vizsgáljuk a fehérje viselkedését olyan különböző oldószerkörülmények között, melyek oldószer-szettekként kereskedelmi forgalomban kaphatók. A kapott eredmények áttekintését és a kristálynövekedés követését a Rock Imager automatizált képalkotó rendszer (Formulatrix) segíti (1. ábra). A készülék a termosztátjában tartott tálcákról programozott időközönként képet készít, mellyel lényegesen megkönnyíti az ígéretes oldatkörülmények megtalálását, emellett az UV-indukálást követő fluoreszcens fény detektálására is alkalmas, amely emisszió a fehérjékre jellemző. Az így kapott képek lehetővé teszik a találatok validálását is mivel azokon a fehérje és só kristályok általában jól megkülönböztethetők. Azonban a tesztek során kapott legnagyobb kristályok is jellemzően olyan kis méretüek, hogy még nem alkalmasak közvetlen diffrakciós mérésre. A nagyobb méretü kristályok előállításához elsőként a szürővizsgálatok során kiválasztott oldatkörülmények finomhangolása ( $\mathrm{pH}$, összetétel) és ezzel párhuzamosan méretnövelés szükséges. A mérésre alkalmas kristályok előállításához szükséges nagyobb oldatmennyiségek könnyen és pontosan kezelhetők manuálisan, ezért az optimálási kísérleteket kézi pipetta segítségével állítjuk össze 24-lyukú tálcán. Az így kapott nagyobb méretü kristályokat a Biostruct laboratóriumban található SuperNova (Agilent Oxford Diffraction) egykristály röntgendiffraktométer segítségével teszteljük (2. ábra). A rézanódos katódsugárcsöves készülék által elöállított mikrofókuszált röntgensugár, a beépített négykörös kappa goniométer és kristályok hütését szolgáló nitrogén hütésü krio-egység a tesztelésen kívül fehérjeszerkezetek meghatározására alkalmas teljes adatkészletek felvételét is lehetővé teszi, akár 1.9Ĺ felbontásban, ha sikerül megfelelő fehérjekristályt növeszteni (2. ábra).
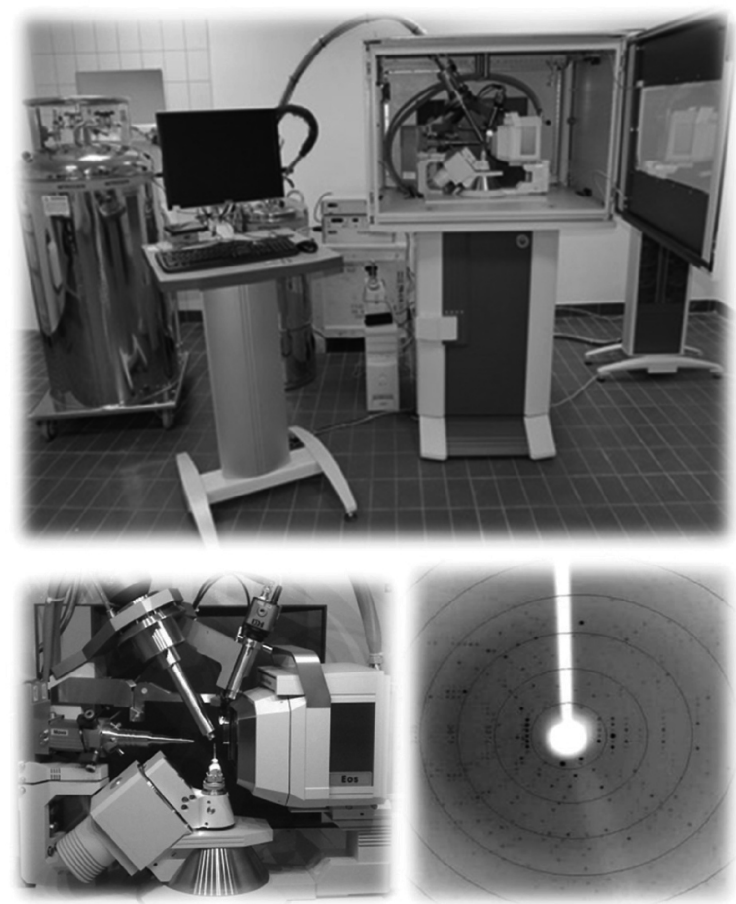

2. ábra. SuperNova röntgen diffrakciós készülék a Biostruct laborban

3. Kurrens kutatások és néhány kiemelt eredmény ${ }^{1-13}$ : Enzimcsaládok a foszfát-csoport átvitelében: nukleofil támadás az alfa-foszfor atomon, mint közös nevező a genom integritásban illetve a lipidanyagcserében szereplő enzimeknél.

A foszfátcsoportnak a biológiában kiemelt jelentősége van. Ezen egyszerü kémiai csoport kismolekulájú metabolitok és fehérje aminosav oldalláncok között való ide-oda adogatása, cseréje, a foszfátészterek és foszforsav anhidridek reakciói meghatározó jelentőségűek számos életfolyamatban (sejtosztódás, egyedfejlődés, jelátvitel, mozgás, biológiai energia, anyagcsere intermedierek aktiválása, nukleinsavak szintézise, másolása, lebontása, stb.). A mi kutatócsoportunk két kitüntetett enzimcsaláddal foglalkozik, melyek a nukleotid anyagcserében (dUTPázok) és a lipid anyagcserében (CTP:foszfokolin-citidililtranszferázok, CCT) játszanak fontos szerepet. Ez a két élettani feladat nagyban különbözik, mégis kémiai szemmel nézve érdekes 
módon összekapcsolja őket az enzimatikus katalízis reakciómechanizmusának lényegi hasonlósága. Nevezetesen, az enzimkatalizált reakció kezdeti lépése a szubsztrát nukleozid-trifoszfátok (dUTP, ill CTP) alfa-foszforatomján történő nukleofil támadás (egy aktivált vízmolekula oxigénje, illetve a foszfokolin foszfátcsoportjának egyik oxigénje által). Ezen kémiai részlet jelentőságét az adja, hogy a nukleozid-trifoszfátok foszfát-transzfer reakcióiban az alfa-P atom reaktivitása kisebb, így az ilyen reakciót katalizáló enzimeknek szükségszerüen nagyobb katalitikus hatékonysággal kell rendelkezniük.

Az elmúlt évek során a dUTPáz enzimcsalád számos képviselőjét (humán, ecetmuslica, retrovirális, fág-eredetü, mikobakteriális, enterobakteriális) vizsgáltuk. A katalizált reakció (dUTP $\rightarrow$ dUMP + pirofoszfát) általánosan hasonló jellegét a szerkezeti biológia és az enzimológia módszereivel jellemeztük. Csoportunk röntgendiffrakciós szerkezetmeghatározáson alapuló eredményei révén ezidáig összesen 48 szerkezetet tettünk közzé a PDB fehérjeszerkezeti adatbázisban, melyek alapján a dUTPázok müködési mechanizmusának alapvető jellegzetességeit tártuk fel ${ }^{3,11,13}$. Ezen tevékenységünkben 2011 óta, a Biostruct laboratórium müködésbe lépését követően nagy segítséget nyújt számunkra, hogy előállított fehérjekristályainkat helyben tesztelhetjük. Megállapítottuk, hogy a katalitikus reakciómechanizmus a különböző eredetű dUTPázok között jelentős hasonlóságokat mutat, de ugyanakkor vannak olyan fajspecifikus jellemzők, melyek alapján fajspecifikus inhibitorok fejlesztése javasolható ${ }^{14}$. Különösen érdekes felfedezést tettünk a Mycobacterium tuberculosis (a tüdőbaj kórokozója) dUTPáz enzime esetében. Kimutattuk ugyanis, hogy a mikobakteriális dUTPáz fehérje egyik fajspecifikus szegmense esszenciális az élőlény túléléséhez ${ }^{15}$. Ez a fajspecifikus szegmens az aktív centrum közelében található, de mégsem vesz részt magában a katalitikus reakcióban (3.ábra). Eltávolítása után a csonkolt enzim továbbra is megőrzi dUTP hidrolizáló hatékonyságát. Ugyanakkor viszont ez a csonkolás a Mycobacterium tuberculosis sejteket halálra ítéli. Ezzel tehát lehetővé vált egy olyan fajspecifikus szegmens azonosítása, amely kismolekulájú gyógyszerjelölt vegyületekkel támadható. Elő is állítottunk számos ilyen gyógyszerjelölt kismolekulát, melyek vizsgálata jelenleg is folyik ${ }^{16,17}$.

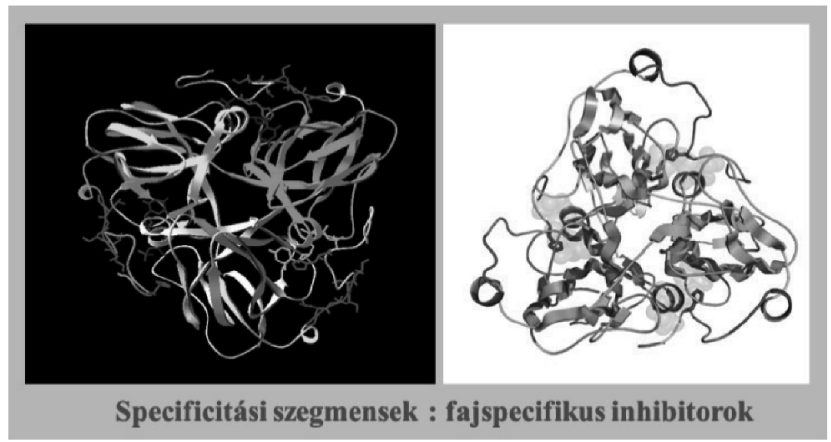

3. ábra. Mycobacterium tuberculosis dUTPáz szerkezete a mikobaktérium-specifikus szegmensek feltüntetésével.
A CTP:foszfokolin citidililtranszferáz enzim (CCT) (EC-szám: 2.7.7.15) a de novo foszfatidilkolin bioszintézis kulcsfontosságú enzime. Az enzim a bioszintetikus útvonal második, sebességmeghatározó lépését katalizálja. Ennek során a kolin-foszfát (ChoP) és CTP reakciójából CDP-kolin (CDPCho) nagyenergiájú metabolikus köztiterméket állít elö, pirofoszfát melléktermék keletkezése mellett. A CCT enzim kolin-fejcsoport szubsztrát-specificitást mutatott, az etanolamin-foszfáttól pa kolin-foszfátig a szubsztrát ammónium csoport fokozatos metilációja az enzim ligand kötő képességének és katalitikus hatékonyságának növekedését eredményezte. Az enzim kolin-kötő zsebe nem mutat szekvenciális és szerkezeti hasonlóságot az evolúciósan rokon CTP:glicerol-3-foszfát citidililtranszferáz (GCT) és CTP:etanolamin-foszfát citidililtranszferáz (ECT) enzimekkel, melyek eltérő szubsztrátokat alakítanak át.

A CDPCho köztiterméken keresztül végbemenő de novo foszfatidilkolin bioszintézis kulcsfontosságú a malária kórokozóját jelentő, a Plasmodium fajokban (Plasmodium falciparum, Plasmodium berghei). A bioszintézis útvonalon belül a CCT egy sebességmeghatározó lépést katalizál. A CCT fehérje a Plasmodium paraziták minden életszakaszában termelődik. Az eddigi kutatások alapján a kolin analóg szerkezetü maláriaellenes hatóanyagcsalád egyik lehetséges gyógyszercélpontját a Plasmodium paraziták CCT enzime jelentheti. Az enzim gyógyszerkölcsönhatásának jellemzéséhez ismernünk kell az enzim szerkezeti felépítését és müködésének jellegzetességeit. A malária napjainkban is az egyik legsúlyosabb fertőző betegség. A világon 3,2 milliárd embert veszélyeztet malária fertőzés, közülük 1,2 milliárdan fokozottan veszélyeztetett területen élnek. A malária jellemzően trópusi betegség, a halálesetek $90 \%$-a Afrikában történik. A terhes nök valamint az 5 év alatti gyermekek kiemelten veszélyeztetettek, utóbbiak teszik ki a malária áldozatainak mintegy háromnegyedét. Az Egészségügyi Világszervezet erőfeszítéseinek köszönhetően a malária által okozott halálozások száma 47 \%-kal csökkent 2000 és 2013 között. 2013-ban azonban így is mintegy 200 millió új malária fertőzést és 584000 halálesetet észleltek. Ezzel a malária több emberéletet követel, mint az összes többi eukarióta eredetü fertőzés együttesen. Kutatócsoportunk egyik kiemelt projektje a Plasmodium falciparum CCT (PfCCT) enzimének tanulmányozása, mind alapkutatási kérdések, mint gyógyszerfejlesztési célok szempontjából.

Kutatásaink során megállapítottuk, hogy a PfCCT aktív hely kolin kötő zsebénél a ligand kötődés elektrosztatikus valamint kation- $\pi$ kölcsönhatások révén valósul meg. Megvizsgáltuk a kölcsönhatásokért felelős oldalláncok egyedi hozzájárulását a megfelelő konzervatív pontmutációik létrehozásával, mely során szerkezetileg hasonló, de eltérő kölcsönhatást biztosító aminosavakra cseréltük őket. Az így létrehozott fehérje konstruktok katalitikus hatékonyságának valamint ligand kötésének vizsgálata során azonosítani tudtuk az egyes oldalláncok ligand kölcsönhatásának meghatározó elektrosztatikus, illetve kation- $\pi$ jellegét. Megmutattuk, hogy mindkét típusú 
kölcsönhatás elengedhetetlen a PfCCT hatékony kvaterner-ammónium ligand kötéséhez, valamint enzim aktivitásához 4. ábra). Eredményeink hozzájárulhatnak a lipid metabolizmus útvonalon ható maláriaellenes hatóanyagok szerkezet alapú fejlesztéséhez.

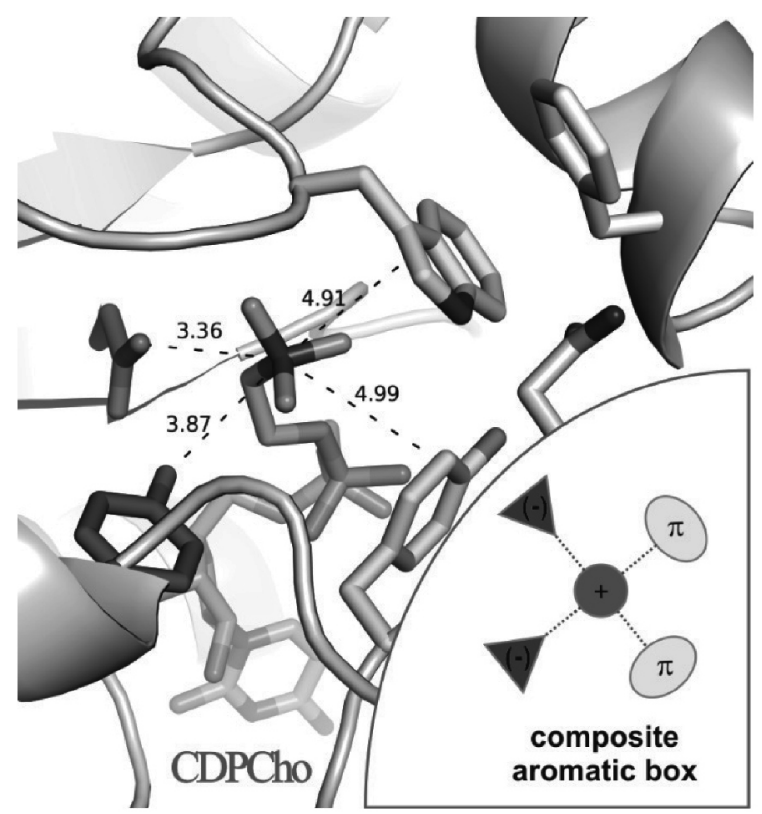

4. ábra. A CDP-kolin ligandum koordinálása a CCT enzim aktív centrumában - közelkép az aktív centrumról. A kiemelt kölcsönhatásokban résztvevő atomok távolságát szaggatott vonalakra írt számok jelölik, melyek angströmben értendők. Az ábrán a következő színkóddal jelöltük a nem-kovalens kölcsönhatásokban résztvevő csoportokat: apoláros kontaktusokban résztvevő oldalláncok C-atomjai sárga színnel, míg a poláros vagy töltött kölcsönhatást biztosító oldalláncok $\mathrm{C}$-atomjai kék színnel, a CDP-kolin ligandum C-atomjai zöld színnel láthatóak, a többi atom a szokásos atomi színkódnak megfelelően vannak színezve (O: piros, $\mathrm{N}$ : kék, P: narancssárga). A CCT fehérje többi feltüntetett C-atomja szürke, továbbá az aktív centrum közeli fehérje-föláncot (peptidvázat) szintén szürke szalagmodell mutatja ${ }^{10}$. A kutatásainkban felderített "composite aromatic box” általános karakterét a jobb alsó betétábra szemlélteti ${ }^{10}$.

\section{Hivatkozások}

1. Kenesi, E., Carbonell, A., Lozsa, R., Vertessy, B. \& Lakatos, L. A viral suppressor of RNA silencing inhibits ARGONAUTE 1 function by precluding target RNA binding to pre-assembled RISC. Nucleic Acids Res, (2017). https://doi.org/10.1093/nar/gkx379

2. Szabo, J. E., Takacs, E., Merenyi, G., Vertessy, B. G. \& Toth, J. Trading in cooperativity for specificity to maintain uracil-free DNA. Sci Rep 6, 24219, (2016). https://doi.org/10.1038/srep24219

3. Nagy, G. N., Suardiaz, R., Lopata, A., Ozohanics, O., Vekey, K., Brooks, B. R., Leveles, I., Toth, J., Vertessy, B. G. \& Rosta, E. Structural Characterization of Arginine Fingers: Identification of an Arginine Finger for the Pyrophosphatase dUTPases. Journal of the American Chemical Society 138, 15035-15045, (2016). https://doi.org/10.1021/jacs.6b09012

4. Lopata, A., Leveles, I., Bendes, A. A., Viskolcz, B., Vertessy, B. G., Jojart, B. \& Toth, J. A Hidden Active Site in the Potential Drug Target Mycobacterium tuberculosis dUTPase Is Accessible through Small Amplitude Protein Conformational Changes. The Journal of biological chemistry 291, 26320-26331, (2016). https://doi.org/10.1074/jbc.M116.734012
A CCT enzim kapcsán felderített ligandum-kötő zseb sajátosságai általános jelentőségü felfedezéshez is elvezettek. Nevezetesen, a PDB (Protein Data Bank) adatbázisban megtalálható makromolekuláris szerkezetek összehasonlító elemzésével rámutattunk, hogy a pozitív töltésü kvaterner ammónium csoportot számos további enzimcsalád hasonló aktív centrumban alakítja át. Ezen fehérjék kötőzsebe ún. „összetett aromás dobozként” (composite aromatic box) írható le, melyet aromás és negatív töltéssel rendelkező oldalláncok alkotnak. Ezzel szemben a korábban felismert ,aromatic box" rigidebb struktúrája elsősorban a receptor (nem enzim) funkcióval rendelkező fehérjékre jellemzö ${ }^{10}$.

A Biostruct laboratórium a magyar szerkezeti biológiai kutatás fontos „,bástyája”, vezető szerepet játszik a hazai röntgendiffrakción alapuló makromolekuláris szerkezeti kutatásokban. A cikkben bemutatott tanulmányok mellett kollaborációs projektekben (többek közt szoros együttműködésben az ELTE Kémiai Intézetében müködő röntgendiffrakciós laboratóriummal) számos makromolekulás és kismolekulás szerkezet megoldásához járultunk hozzá. A továbbiakban is nyitottak vagyunk hasonló együttmüködések kialakítására.

\section{Köszönetnyilvánítás}

Köszönetet mondunk az alábbi pályázati forrásoknak: NKFIH OTKA NK 84008, K109486, K119493, K111024, Új Magyarország Fejlesztési program - Baross program 3DSTRUCT, OMFB-00266/2010 REG-KM-09-1-20090050, Magyar Tudományos Akadémia TTK IF-28/2012, Varga József Alapítvány, European Commission FP6 STREP 012127, FP7 SPINE2c LSHG-CT-2006-031220 and FP7 Biostruct-X projekt (\#283570), Howard Hughes Medical Institutes ((\#55005628 és \#55000342), USA.

5. Christie, M., Chang, C.-W., Rona, G., Smith, K. M., Stewart, A. G., Takeda, A. A. S., Fontes, M. R. M., Stewart, M., Vertessy, B. G., Forwood, J. K. \& Kobe, B. Structural Biology and Regulation of Protein Import into the Nucleus. J Mol Biol 428, 2060-2090, (2016). https://doi.org/10.1016/j.jmb.2015.10.023

6. Nyiri, K., Kohegyi, B., Micsonai, A., Kardos, J. \& Vertessy, B. G. Evidence-Based Structural Model of the Staphylococcal Repressor Protein: Separation of Functions into Different Domains. PloS one 10, e139086, (2015). https://doi.org/10.1371/journal.pone.0139086

7. Hirmondo, R., Szabo, J. E., Nyiri, K., Tarjanyi, S., Dobrotka, P., Toth, J. \& Vertessy, B. G. Cross-species inhibition of dUTPase via the Staphylococcal Stl protein perturbs dNTP pool and colony formation in Mycobacterium. DNA Repair (Amst) 30, 21-27, (2015). https://doi.org/10.1016/j.dnarep.2015.03.005

8. Szabo, J. E., Nemeth, V., Papp-Kadar, V., Nyiri, K., Leveles, I., Bendes, A. A., Zagyva, I., Rona, G., Palinkas, H. L., Besztercei, B., Ozohanics, O., Vekey, K., Liliom, K., Toth, J. \& Vertessy, B.G. Highly potent dUTPase inhibition by a bacterial repressor protein reveals a novel mechanism for gene expression control. Nucleic Acids Res 42, 11912-11920, (2014). https://doi.org/10.1093/nar/gku882 
9. Rona, G., Borsos, M., Ellis, J. J., Mehdi, A. M., Christie, M., Kornyei, Z., Neubrandt, M., Toth, J., Bozoky, Z., Buday, L., Madarasz, E., Boden, M., Kobe, B. \& Vertessy, B. G. Dynamics of re-constitution of the human nuclear proteome after cell division is regulated by NLS-adjacent phosphorylation. Cell cycle 13, 3551-3564, (2014). https://doi.org/10.4161/15384101.2014.960740

10. Nagy, G. N., Marton, L., Contet, A., Ozohanics, O., Ardelean, L.-M., Revesz, A., Vekey, K., Irimie, F. D., Vial, H., Cerdan, R. \& Vertessy, B. G. Composite aromatic boxes for enzymatic transformations of quaternary ammonium substrates. Angewandte Chemie 53, 13471-13476, (2014). https://doi.org/10.1002/anie.201408246

11. Rona, G., Marfori, M., Borsos, M., Scheer, I., Takacs, E., Toth, J., Babos, F., Magyar, A., Erdei, A., Bozoky, Z., Buday, L., Kobe, B. \& Vertessy, B. G. Phosphorylation adjacent to the nuclear localization signal of human dUTPase abolishes nuclear import: structural and mechanistic insights. Acta Crystallographica Section D D69, 2495-2505 (2013). https://doi.org/10.1107/S0907444913023354

12. Leveles, I., Nemeth, V., Szabo, J. E., Harmat, V., Nyiri, K., Bendes, A. A., Papp-Kadar, V., Zagyva, I., Rona, G., Ozohanics, O., Vekey, K., Toth, J. \& Vertessy, B.G. Structure and enzymatic mechanism of a moonlighting dUTPase. Acta Crystallogr D Biol Crystallogr 69, 2298-2308, (2013). https://doi.org/10.1107/S0907444913021136

13. Barabas, O., Németh, V., Bodor, A., Perczel, A., Rosta, E., Kele, Z., Zagyva, I., Szabadka, Z., Grolmusz, V., Wilmanns, M. \& Vertessy, B. G. Catalytic mechanism of alpha-phosphate attack in dUTPase is revealed by X-ray crystallographic snapshots of distinct intermediates, 31P-NMR spectroscopy and reaction path modelling. Nucleic Acids Res, (2013). https://doi.org/10.1093/nar/gkt756

14. Nyiri, K. \& Vertessy, B. G. Perturbation of genome integrity to fight pathogenic microorganisms. Biochimica et biophysica acta 1861, 3593-3612, (2017).

https://doi.org/10.1016/j.bbagen.2016.05.024
15. Pecsi, I., Hirmondo, R., Brown, A.C., Lopata, A., Parish, T., Vertessy, B.G. \& Toth, J.The dUTPase enzyme is essential in Mycobacterium smegmatis. PloS one 7, e37461, (2012). https://doi.org/10.1371/journal.pone.0037461

16. Horvati, K., Bacsa, B., Szabo, N., Fodor, K., Balka, G., Rusvai, M., Kiss, E., Mezo, G., Grolmusz, V., Vertessy, B., Hudecz, F. \& Bosze, S. Antimycobacterial activity of peptide conjugate of pyridopyrimidine derivative against Mycobacterium tuberculosis in a series of in vitro and in vivo models. Tuberculosis 95 Suppl 1, S207-211, (2015). https://doi.org/10.1016/j.tube.2015.02.026

17. Horvati, K., Bacsa, B., Szabo, N., David, S., Mezo, G., Grolmusz, V., Vertessy, B. G., Hudecz, F. \& Bosze, S. Enhanced Cellular Uptake of a New, in Silico Identified Antitubercular Candidate by Peptide Conjugation. Bioconjug Chem 23, 900-907, (2012). https://doi.org/10.1021/bc200221t

18. Varga, B., Barabas, O., Takacs, E., Nagy, N., Nagy, P. \& Vertessy, B.G. Active site of mycobacterial dUTPase: structural characteristics and a built-in sensor. Biochem Biophys Res Commun 373, 8-13, (2008). [pii] https://doi.org/10.1016/j.bbrc.2008.05.130

19. Marton, L., Nagy, G. N., Ozohanics, O., Labas, A., Kramos, B., Olah, J., Vekey, K. \& Vertessy, B.G. Molecular Mechanism for the Thermo-Sensitive Phenotype of CHO-MT58 Cell Line Harbouring a Mutant CTP:Phosphocholine Cytidylyltransferase. PloS one 10, e0129632, (2015).

https://doi.org/10.1371/journal.pone.0129632

20. Nagy, G. N., Marton, L., Kramos, B., Olah, J., Revesz, A., Vekey, K., Delsuc, F., Hunyadi-Gulyas, E., Medzihradszky, K.F., Lavigne, M., Vial, H., Cerdan, R. \& Vertessy, B. G. Evolutionary and mechanistic insights into substrate and product accommodation of CTP:phosphocholine cytidylyltransferase from Plasmodium falciparum. FEBS J 280, 3132-3148, (2013). https://doi.org/10.1111/febs.12282

\section{Structural biology studies at the BME Biostruct Laboratory by X-ray crystallography}

Investigation of the biochemical basis of life is a long standing challenge for scientists. The field of molecular biology was established based on the pioneering studies of macromolecular structures, including the structural characterization of the DNA double helix and the description of the first protein structures. These early achievements along with the technical development, e.g. automatic data collection and computer-assisted data analysis enables extremely efficient and fast determination of structure and dynamic properties of proteins. The sequencing of the human genome revealed the genetic code of life, however there is still much to explore about structure and function of vital macromolecules. Although computer-based, in silico structure prediction methods are rapidly developing, reliable determination of protein structure is yet only possible based on additional analysis of experimental data. Towards this end, integrated structural biology allows us to obtain insights into structure-function relationships of macromolecules and their complexes with hitherto unprecedented details. The core of such studies relies on three dimensional structural
(3D) determination by X-ray crystallography or multidimensional nuclear magnetic resonance (NMR), as well as cryo-electron microscopy (cryo-EM). An increasingly widespread approach additionally includes the additional employment of small angle X-ray scattering (SAXS), hydrogen deuterium exchange mass spectrometry (HDX-MS), chemical crosslinking and fluorescent spectroscopic techniques to provide complementary information to the aforementioned techniques. Further biophysical techniques including isothermal titration calorimetry (ITC) or microscale thermophoresis (MST) and spectroscopic analysis (fluorimetry, CD, UV-VIS, NIR, Raman) also contribute to a more in-depth understanding of protein form and function. Last but not least, emergent new hypotheses additionally provided by the dynamically expanding field of computational methods including quantum mechanics and molecular dynamics calculations. This approach is collectively referred as integrated structural biology, which is perhaps one of the most dynamically expanding field of life sciences. 
The X-ray crystallography technique employed by our group is a key element of the methods' repertoire since it has the great advantage that the size of the target is theoretically not limited. Structural insights can be acquired by X-ray diffraction from molecules that encompasses the complete size range starting from ions, small peptide hormones, large protein complexes up to that of entire viruses. This method provides high, sometimes atomic level resolution structural information about the sample depending on the X-ray source and crystal quality. The widespread access of the X-ray crystallographer community to high brilliance synchrotron $\mathrm{X}$-ray photon sources as well as to the wide range of automatized or easy-to-use computational structure determination methods promotes the popularity of this experimental technique and enables its application to large-scale screening and structure based development of drug candidates.

Here we describe the infrastructure available at the Biostruct macromolecular crystallography laboratory founded in 2011 at the Budapest University of Technology and Economics. The first step of macromolecular crystallography is to find the conditions which result in crystal formation from the supersaturated solution of the protein. We benefit from the assistance of a high throughput liquid-handling robot (Mosquito, TTP Labtech) to set up 96-well plates with 50-100 $\mathrm{nl}$ drops of protein mixed with the crystallization solution. The crystal formation in the drops is followed by the Rock Imager automated imaging system (Formulatrix). The initial hits can be assessed based on UV-fluorescence emission, which provides fast and efficient way to discriminate protein and salt crystals. Optimization and fine tuning of conditions to gain $3 \mathrm{D}$ crystals with $\mu \mathrm{m}$ dimensions for diffraction experiments are performed on 24-well trays, where crystallization is set up manually. The X-ray diffraction pattern of the crystals are recorded by a SuperNova (Agilent Oxford Diffraction) microfocus X-ray diffractometer equipped with a CCD detector applying cryo conditions.

Relying on crystallography and structural biology (cf. a total of 48 structures have been deposited by our research group to the Protein Data Bank), our research topics at the Biostruct laboratory focus on enzymes involved in phosphate transfer reactions either in nucleotide metabolism / DNA repair or in lipid biosynthesis. Within the past two decades we provided essential contribution to the characterization of the deoxyuridine 5'-triphosphate nucleotidohydrolase (dUTPase, enzyme commission (EC) number: 3.6.1.23) enzyme family by characterizing its multiple orthologues including human, drosophila, retroviral, phage-like, mycobaterial and enterobacterial variants. Structural analysis of dUTPase enabled us to provide insights into the conserved catalytic mechanism of these enzymes as well as to discover species-specific segments that could provide a selective target in fighting deadly human pathogens. One of the most interesting piece of evidence results was obtained for the dUTPase of Mycobacterium tuberculosis, the bacterium responsible for tuberculosis. We have shown that the mycobacterial dUTPase has a species specific segment close to its active site that is dispensable for its catalytic mechanism. Nevertheless, this segment was found to be essential in vivo based on cellular studies performed using the closely related Mycobacterium smegmatis model organism. Subsequent ongoing studies are in progress in our laboratory to characterize the yet unknown function of this drug target species specific segment and to develop novel inhibitors against Mycobacteria.

An additional research area in our laboratory focuses on the structure-based characterization of a key lipid biosynthesis enzyme of the Plasmodium malaria causative agents. The Plasmodium falciparum CTP:phosphocholine cytidylyltransferase (PfCCT, EC: 2.7.7.15) catalyzes a rate-limiting step in de novo phosphatidylcholine biosynthesis of the parasite and has been validated as a potential antimalarial drug target. Beyond the enzymatic characterization of a construct encompassing the catalytic domain of PfCCT, our research focuses on deciphering of ligand recognition at the choline binding subpocket of the active site, which is a probable interaction surface of choline-mimicking antimalarial drugs. We engineered point mutants for choline interacting residues at the active site of $P f C C T$ to test their contribution to ligand binding and catalytic efficiency. Our results indicate that electrostatic and cation-đ interactions from charged and aromatic residues are both essential for efficient ligand recognition and conversion at this enzyme subsite. We additionally observed through a comprehensive analysis of deposited protein structures that such a combination of aromatic and charged ligand recognition pattern termed as composite aromatic box has been emerged as a widespread structural solution for coordination of quaternary ammonium ligands by enzymes. Notably, this binding motif is clearly distinct from the well-known aromatic box or aromatic cage architecture found abundantly at receptor proteins without enzymatic function. The presented ligand recognition patterns are critical for the mechanism of action for enzymes and receptors from neurotransmission, lipid biosynthesis, cellular defense and epigenetics.

In addition to these exemplary studies shown here as snapshots, several other research projects on small molecular and macromolecular structure determination are running at the Biostruct laboratory many of which is realized within a collaborative framework. 